УДК 633.11:665.526.81

(C) 2013

Козелець Г. М., науковий співробітник

Кіровоградська державна сільськогосподарська дослідна станція ІСГСЗ НААН

\title{
ПРОДУКТИВНІСТЬ КОРІАНДРУ ЗАЛЕЖНО ВІД СТРОКІВ СІВБИ, НОРМИ ВИСІВУ ТА ШИРИНИ МІЖРЯДЬ У ПІВНІЧНОМУ СТЕПУ УКРАЇНИ
}

\section{Рецензент - кандидат сільськогосподарських наук Н. Л. Умрихін}

\begin{abstract}
Наведено результати досліджень впливу норми висіву і ширини міжрядь на продуктивність коріандру за підзимового та ранньовесняного строків сівби. Встановлено, щу кращим строком сівби для коріандру є підзимовий, за якого врожайність плодів становила $1,21 \mathrm{~m} / 2$, щуо більше порівняно із ранньовесняним на 0,30 m/2а, або 24,7\%. Для коріандру в умовах північного Степу оптимальною є норма висіву 2,02,5 млн сх. нас. на 1 га, яка забезпечила урожайність 1,14-1,15 m/2а. Сівба з иириною міжрядь 0,45 м сприяла отриманню врожсайності 1,09 m/2а, щзо більше ніж при 0,15 м на 0,06 m/2a, або 8,0\%. Вищий рівень врожаю $(1,39 \mathrm{~m} / 2 a)$ отримано за підзимового строку сівби з шириною міжрядь 0,45 м та нормою висіву 2,0 млн сх. нас. на 1 га.
\end{abstract}

Ключові слова: коріандр, продуктивність, строки сівби, ширина міжрядь, норми висіву.

Постановка проблеми. У період сучасного розвитку сільського господарства та нестабільності цін на продукцію сільськогосподарського виробництва необхідно знаходити нові шляхи отримання прибутку за рахунок введення у сівозміну нових нетрадиційних культур. Однією 3 таких культур є коріандр, який, завдяки своїми морфолого-біологічним властивостям, здатний формувати високі врожаї в умовах північного Степу України [3].

За останні роки значно підвищився попит на товарне насіння коріандру, що стало продуктом експорту $[3,6]$. Тому необхідно збільшувати посівні площі під даною культурою - це забезпечить більш ефективне використання земельних угідь та позитивний вплив на економіку сільськогосподарських підприємств степової зони України.

Аналіз останніх досліджень і публікацій, у яких започатковано розв'язання проблеми. Серед ефіроолійних культур, які вирощують у сільському господарстві, досить важливою є коріандр [5]. Коріандр - найбільш дешева сировина багатоцільового призначення. Його використовують у парфумерно-косметичній, харчовій, хіміко-фармацевтичній, лакофарбовій, поліграфічній, текстильній промисловості тощо.

Ефірна олія, яку добувають із його плодів, є по- чатковим продуктом для отримання речовин із запахом лимона, помаранча, бергамоту, троянди, фіалки, лілії та інших, що використовуються в парфумерній промисловості для виготовлення парфумів, одеколону, туалетного мила [2, 4]. Різноманітність ароматичних речовин, які отримують iз коріандрової ефірної олії, ставить його поруч із найціннішими сировинними культурами $[1,2]$.

Сорти коріандру мають високий потенційний рівень врожайності та якості плодів. Однак, за останні роки середня врожайність у зоні північного Степу України знаходиться в межах 0,6-0,7 т/га. Низький рівень врожайності коріандру можна пояснити відсутністю розроблених елементів технології його вирощування 3 урахуванням особливостей грунтово-кліматичних умов даної зони та властивостей нових сортів. Коріандр вирощується згідно з загальноприйнятою технологією для південного Степу, проте в умовах північного Степу України він може забезпечувати врожайність у межах 2,0-2,5 т/га, а також високий рівень рентабельності даної культури.

Мета досліджень. Зважаючи на вищевикладене, метою наших досліджень було встановити вплив строків сівби, ширини міжрядь та норми висіву на продуктивність коріандру за ранньовесняного та підзимового строку сівби.

Завдання досліджень:

- визначити ефективніший строк сівби для коріандру в умовах північного Степу України;

- визначити оптимальну норму висіву насіння коріандру за різної ширини міжрядь;

- встановити вплив вищенаведених агротехнічних заходів на урожайність коріандру.

Матеріали і методи досліджень. Дослідження проводили на Кіровоградській ДСГДС ІСГС3 НААН протягом 2007-2010 рр. у насінницькій сівозміні лабораторії селекції та первинного насінництва. Грунт дослідної ділянки - чорнозем звичайний середньогумусний важкосуглинковий iз вмістом гумусу в орному шарі 4,63 \%, легкогідролізованого азоту (за Корнфілдом) - 12,0, рухомого фосфору та обмінного калію (за Чиріковим) - 11,6 та 11,8 мг на 100 г грунту відповідно. 
Реакція грунтового розчину нейтральна: $\mathrm{pH}_{\text {сол }}=$ 5,4, гідролітична кислотність - 1,23-2,10 мг-екв на 100 г абсолютно сухого грунту.

У ході проведення досліджень керувалися загальноприйнятою методикою Б. А. Доспєхова та методикою 3 проведення польових і вегетаційних досліджень на ефіроолійних культурах (Сімферополь, 1985).

Схема досліду передбачала:

- фактор А (строки сівби): 1) підзимовий;

2) ранньовесняний;

- фактор В (ширина міжрядь): 1) 0,15 м; 2) 0,45 м;

- фактор С (норма висіву насіння коріандру):

1) 1,5 млн сх. нас./га; 2) 2,0 млн сх. нас./га; 3) 2,5 млн сх. нас./га; 4) 3,0 млн сх. нас./га.

Попередник - пшениця озима після чорного пару. Дослід закладали методом розщеплених ділянок, повторність - чотириразова. Площа посівної ділянки $-36 \mathrm{~m}^{2}$, облікової - $18 \mathrm{~m}^{2}$. У дослідах вирощували сорт коріандру Оксаніт. Сівбу проводили селекційною сівалкою СКС-6-10 та СН-10 (залежно від варіантів) за підзимового строку сівби 01.11.2006 p., 01.11.2007 p., 02.11.2008 p., 03.11.2009 р.; ранньовесняного 20.03.2007 p., $\quad 26.03 .2008$ p., $\quad 04.04 .2009$ p., 01.04.2010 року.

Найсприятливішим за режимом зволоження в основні фази росту та розвитку рослин коріандру був 2009 рік, найменш сприятливим - 2007 рік. У цілому погодні умови 2006-2010 рр. були типовими для північного Степу України, що дозволило виявити вплив температурного режиму та зволоження грунту у період вегетації на ефективність вирощування коріандру за різних строків сівби.

Результати досліджень. У процесі вирощування коріандру необхідно враховувати не тільки особливості обробітку грунту, а й досягнення оптимальної площі живлення культури. Особливе значення на темпи проходження фенологічних фаз росту і розвитку, щільність посівів, біометричні показники, індивідуальну продуктивність рослин та врожайність плодів мають способи сівби і норма висіву.

Спосіб сівби і густота рослин є основними складовими агротехніки коріандру, поскільки лише правильно вибравши ширину міжрядь i норму висіву можна досягти оптимального розвитку й реалізації ними потенційної продуктивності. Рослини коріандру досить чутливі до зміни площі живлення, що, в свою чергу, впливає на облистненість, інтенсивність фотосинтезу, гілкування, висоту прикріплення нижніх зонтиків, кількість продуктивних зонтиків і визначає в кінцевому результаті величину та якість урожаю.

Формування густоти стояння рослин починається вже під час сівби, поскільки нормою висіву можна закласти оптимальний стеблостій. Проте кількість рослин, що утворюється після проростання насіння, не вдається зберегти до періоду дозрівання та збирання врожаю. Протягом вегетаційного періоду кількість рослин на одиниці площі поступово зменшується. Збільшення норми висіву 3 1,5 до 3,0 млн. схожих насінин на 1 га призводило до зниження густоти стояння рослин на $2,5-5,0 \%$. Зі збільшенням ширини міжрядь із 0,15 м до 0,45 м даний показник зменшувався на 2,5-3,5 \%. Вищі показники польової схожості насіння було отримано у варіантах 3 шириною міжрядь 0,15 м за норми висіву насіння 1,5 млн сх. нас. на 1 гектар.

Дослідженнями встановлено: збільшення норми висіву призводило до зниження виживаності рослин протягом вегетаційного періоду. Переважна кількість рослин, що збереглися до збирання, була у варіантах із шириною міжрядь 0,15 м за норми висіву 1,5 млн сх. нас. на 1 га, а ïх виживаність становила 94,8-95,0\%. Найменший показник збережених рослин був за сівби 3 шириною міжрядь 0,45 м та нормою висіву насіння 3,0 млн сх. нас. на 1 га і становив 85,0$90,0 \%$.

Площа листової поверхні рослин коріандру за підзимового строку сівби, у порівнянні з ранньовесняним $\left(80,6 \mathrm{~cm}^{2}\right)$, була більшою на $6-10 \%$ i становила $88,0 \mathrm{~cm}^{2}$ (табл. 1).

Зі збільшенням норми висіву площа листової поверхні однієї рослини зменшувалася. Так, за норми висіву 1,5 млн сх. нас. на 1 га, вона, в середньому, за строками сівби становила $90,8 \mathrm{~cm}^{2}$ на рослину, тоді як за норм висіву 3,0 млн сх. нас. на 1 га $-76,7 \mathrm{~cm}^{2}$.

Залежно від ширини міжрядь встановлено деякі зміни площі листової поверхні рослин коріандру, на варіантах із міжряддям 0,45 м вона була більшою на 8-10\% порівняно з 0,15 метра. У середньому за ширини міжрядь 0,15 м площа листової поверхні становила $81,3 \mathrm{~cm}^{2}$, а за $0,45 \mathrm{~m}$ $-87,3 \mathrm{~cm}^{2}$.

Способи сівби та норми висіву впливали на зміну біометричних показників та індивідуальну продуктивність рослин коріандру: збільшення ширини міжрядь сприяло утворенню більшої кількості плодів на рослині, а збільшення норми висіву в межах способу сівби, навпаки, спричиняло зменшення їх кількості. Тобто, за збільшення ширини міжрядь зростає індивідуальна продуктивність рослин коріандру. 
1. Площа листової поверхні рослин коріандру залежно від строку, способів сівби та норми висіву, $\mathrm{cm}^{2} /$ рослину (2007-2010 рр.)

\begin{tabular}{|c|c|c|c|c|c|c|}
\hline \multirow{2}{*}{ Строк сівби } & \multirow{2}{*}{$\begin{array}{c}\text { Ширина } \\
\text { міжрядь, м }\end{array}$} & \multicolumn{4}{|c|}{ Норма висіву, млн. схожих насінин на 1 га } & \multirow{2}{*}{$\begin{array}{c}\text { Середнє } \\
\text { по ширині } \\
\text { міжрядь }\end{array}$} \\
\hline & & 1,5 & 2,0 & 2,5 & 3,0 & \\
\hline \multirow{3}{*}{ Підзимовий } & 0,15 & 90,2 & 89,4 & 83,1 & 78,9 & 85,4 \\
\hline & 0,45 & 98,9 & 92,6 & 88,4 & 82,5 & 90,6 \\
\hline & середнє & 94,6 & 91,0 & 85,7 & 80,7 & 88,0 \\
\hline \multirow{3}{*}{ Ранньовесняний } & 0,15 & 83,1 & 81,1 & 75,6 & 68,9 & 77,2 \\
\hline & 0,45 & 90,6 & 87,5 & 81,1 & 76,3 & 83,9 \\
\hline & середнє & 86,9 & 84,3 & 78,4 & 72,6 & 80,6 \\
\hline
\end{tabular}

2. Урожайність коріандру залежно від строків, способів сівби та норми висіву насіння, $\mathrm{m} / 2 а$ (2007-2010 pp.)

\begin{tabular}{|c|c|c|c|c|c|c|}
\hline $\begin{array}{c}\text { Строк } \\
\text { сівби } \\
\text { (фактор А) } \\
\end{array}$ & \begin{tabular}{|c|} 
Ширина \\
міжрядь, м \\
(фактор В) \\
\end{tabular} & $\begin{array}{c}\text { Норма висіву насін- } \\
\text { ня, млн сх. нас./га } \\
\text { (фактор С) }\end{array}$ & $\begin{array}{l}\text { Урожай- } \\
\text { ність, т/га }\end{array}$ & $\begin{array}{c}\text { Середнє } \\
\text { фактора A }\end{array}$ & $\begin{array}{c}\text { Середнє } \\
\text { фактора В }\end{array}$ & $\begin{array}{l}\text { Середнє } \\
\text { фактора С }\end{array}$ \\
\hline \multirow{8}{*}{ 恣 } & \multirow{4}{*}{0,15} & 1,5 & 1,13 & \multirow{8}{*}{1,21} & \multirow{4}{*}{1,03} & 0,95 \\
\hline & & 2,0 & 1,22 & & & 1,14 \\
\hline & & 2,5 & 1,29 & & & 1,15 \\
\hline & & 3,0 & 1,08 & & & 1,01 \\
\hline & \multirow{4}{*}{0,45} & 1,5 & 1,04 & & \multirow{4}{*}{1,09} & \\
\hline & & 2,0 & 1,39 & & & \\
\hline & & 2,5 & 1,35 & & & \\
\hline & & 3,0 & 1,17 & & & \\
\hline \multirow{8}{*}{ 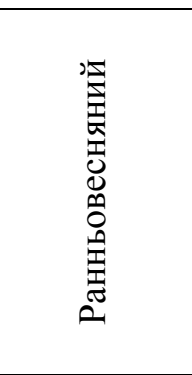 } & \multirow{4}{*}{0,15} & 1,5 & 0,81 & \multirow{8}{*}{0,91} & & \\
\hline & & 2,0 & 0,89 & & & \\
\hline & & 2,5 & 0,97 & & & \\
\hline & & 3,0 & 0,84 & & & \\
\hline & \multirow{4}{*}{0,45} & 1,5 & 0,81 & & & \\
\hline & & 2,0 & 1,05 & & & \\
\hline & & 2,5 & 0,98 & & & \\
\hline & & 3,0 & 0,94 & & & \\
\hline $\mathrm{HIP}_{05}$ & \multicolumn{3}{|c|}{$\begin{aligned} \mathrm{ABC} & =0,05-0,08 ; \mathrm{AB}=0,02-0,06 ; \\
\mathrm{AC} & =0,02-0,04 ; \mathrm{BC}=0,03-0,05\end{aligned}$} & $00,2-0,06$ & $0,02-0,04$ & $0,01-0,03$ \\
\hline
\end{tabular}

У середньому більша маса 1000 насінин була отримана у варіантах із шириною міжрядь 0,45 м і нормою висіву 1,5 млн сх. нас. на 1 га $-8,5$ г та 3 аналогічною нормою за ширини 0,15 м - 7,6 грама. За збільшення норми висіву (незалежно від ширини міжрядь) відмічено зменшення маси 1000 насінин з 8,6 г до 6,1 грама.

Врожайність коріандру, як і інших сільськогосподарських культур, залежить від індивідуальної продуктивності рослин та їх кількості на одиниці площі. Найвища їх врожайність формується за оптимального їх співвідношення. Строки сівби мали суттєвий вплив на зміну рівня врожайності коріандру. Так, за підзимового строку сівби врожайність, залежно від варіантів, коливалася в межах 1,04-1,39 т/га, а за ранньо- весняного - 0,81-0,98 т/га (табл. 2).

Більша врожайність сформувалась у варіантах за підзимового строку сівби із шириною міжрядь 0,45 м та нормою висіву 2,0 млн сх. нас. на 1 га i становила 1,39 т/га. Найменша $(0,81$ т/га) - за ранньовесняного строку з нормою висіву 1,5 млн cх. нас. на 1 гектар.

Аналізуючи продуктивність коріандру, слід зауважити: за сівби 3 шириною міжрядь 0,45 м урожайність була 1,09 т/га, що більше на 5-8 \%, ніж за 0,15 метра. Оптимальною для коріандру в умовах північного Степу була норма висіву 2,0 2,5 млн сх. нас. на 1 га, яка забезпечувала урожайність 1,14-1,15 т/га. За сівби нормою 3,0 млн cx. нас. на 1 га відмічено зниження урожайності на 0,14 т/га, а при 1,5 млн $-0,19$ т/га. 
Висновок. Кращим строком сівби для коріандру є підзимовий, за якого врожайність плодів становила 1,21 т/га, що більше, порівняно із ранньовесняним, на 0,30 т/га, або $24,7 \%$.

Для коріандру в умовах північного Степу оптимальною $є$ норма висіву 2,0-2,5 млн сх. нас. на 1 га, що забезпечила урожайність 1,14-1,15 т/га.

\section{БІБЛІОГРАФІЯ}

1. Беляев В. А. Пряновкусовые растения, их свойства и применение / В. А. Беляев. - М. : Сельхозиздат, $-1946 .-112 \mathrm{c}$.

2. Бринк И. П. Пряные растения / И. П. Бринк. М. : Сельхозиздат, $-1956 .-23 \mathrm{c}$.

3. Зубещь М. В. Наукові основи агропромислового виробництва в зоні Степу України / М. В. Зубець (голова редакційної колегії) та ін. - К. : Аграрна наука, 2004. - С. 325-326.
Сівба з шириною міжрядь 0,45 м сприяла отриманню врожайності 1,09 т/га, що більше ніж за 0,15 м на 0,06 т/га, або $8,0 \%$.

Вищий рівень врожаю $(1,39$ т/га) отримано за підзимового строку сівби 3 шириною міжрядь 0,45 м та нормою висіву 2,0 млн сх. нас. на 1 гектар.

4. Столетова Е. А. Коріандр / Е. А. Столетова М.-Л.: Огиз, Гос. изд. с.-х. колхоз.-кооп. литературы, Гидр. упр., $-1931 .-68$ с.

5. Хотина А. А. Эфиромасличные культуры / Под ред. А. А. Хотина, Г. Т. Шульгина. - М., Сельхозиздат, $1963 .-359 \mathrm{c}$.

6. Юркевич Ю. Коріандр - попит збільшується / Ю. Юркевич // Пропозиція. - 2007. - № 9. C. 66-68. 